\title{
Biodiversity inventory of trees in a neotropical secondary forest after abandonment of shaded coffee plantation
}

\author{
Norberto Emídio Oliveira-Neto(1), \\ Diego Raymundo Nascimento ${ }^{(1)}$, \\ Fabrício Alvim Carvalho ${ }^{(2)}$
}

\begin{abstract}
Tree structure and diversity of a secondary Atlantic Forest resulting from the abandonment (ca. 70 years) of a shaded coffee (Coffea arabica) plantation was studied in southeastern Brazil. All trees with DBH $\geq 5 \mathrm{~cm}$ (alive and dead) were measured in 25 plots of $20 \times 20 \mathrm{~m}$. Out of the 1926 sampled trees, 1837 were living trees belonging to 116 species. The most important species (importance value - IV) in the community were Euterpe edulis $(22.9 \%$ - present in all plots) and Piptadenia gonoacantha (16.5\%). Euterpe edulis is a typical palm tree of high importance value in mature forests, comprising $41.2 \%$ of individuals. The results show a more mature tree community in relation to other secondary forests with the same abandonment period in the region, with high richness and diversity of species, high basal area, and low dead tree density. In addition, several endangered species were recorded with high conservation value for the regional flora. The results also showed many typical characteristics of "novel ecosystems" discussed here in order to value these environments, still neglected due to strong environmental human alterations.
\end{abstract}

\section{Keywords: Brazilian Atlantic Forest, Forest Succession, Novel Ecosystem, Agro-} forestry tential to remain ecologically untapped due to their rapid growth characteristics (Guariguata \& Ostertag 2001). Its vast extension in humid tropics and its predominance in biomes such as the Brazilian Atlantic Forest, calls for an increased understanding and appreciation of the environmental services provided by these forests by addressing the existing research gaps and providing the scientific basis of reforestation and restoration methods (Chazdon et al. 2009).

Phytosociological studies conducted in forest fragments in southeastern Brazil provided important advances to the knowledge of forest succession under anthropogenic influence (Valente et al. 2011, Fonseca \& Carvalho 2012, Moreira \& Carvalho 2013, Brito \& Carvalho 2014, Carvalho et al. 2014, Moreira 2014). Such information may help planning of appropriate management practices, particularly where species with viable economic production are present in the $\square$ (1) Programa de Pós-graduação em Ecologia, Instituto de Ciências Biológicas, Universidade Federal de Juiz de Fora, Campus Universitário, no number, São Pedro, 36036-900, Juiz de Fora-MG (Brazil); (2) Departamento de Bot'nica, Universidade Federal de Juiz de Fora, Campus Universitário, no number, São Pedro. 36036-900, Juiz de Fora-MG (Brazil)

@ Norberto Emídio Oliveira-Neto (norbertoemidio@gmail.com)

Received: Oct 20, 2015 - Accepted: Sep 14, 2016

Citation: Oliveira-Neto NE, Nascimento DR, Carvalho FA (2017). Biodiversity inventory of trees in a neotropical secondary forest after abandonment of shaded coffee plantation. iForest 10: 303-308. - doi: 10.3832/ifor1901-009 [online 2017-02-23]

Communicated by: Raffaele Lafortezza study area. Chazdon et al. (2009) claim that the management of secondary formations is one of the greatest potential solutions to increasing biodiversity conservation of tropical forests, including Brazilian forests.

This study focused on a secondary Atlantic Forest formerly used as a shaded coffee plantation (Coffea arabica), that has been naturally regenerating in the last 70 years after abandonment. The main goal was to evaluate the structure and species diversity of its tree regenerating community. We tested the hypothesis that the forest would present distinct successional tree community indicators (structural and diversity parameters) in comparison with secondary forests studied to date, with the same abandonment time in the region, due to its history of regeneration from shaded plantations.

\section{Materials and methods}

The study area was located in an Atlantic Forest fragment that belongs to the Federal University of Juiz de Fora Botanical Garden (JB-UFJF) in the city of Juiz de Fora, Minas Gerais, southeastern Brazil (Fig. 1). The JB-UFJF covers about 80 ha and is contiguous to the Environmental Protection Area of "Mata do Krambeck" forest, forming an extensive urban forest remnant with a total area of approx. 370 ha. According to Köppen, the climate is humid subtropical (Cwa) with two distinct seasons: summerspring, with higher temperatures and rainfall (October to April); and autumn-winter, which is colder and drier (May to September - Fonseca \& Carvalho 2012). The annual rainfall average is close to $1500 \mathrm{~mm}$, with 


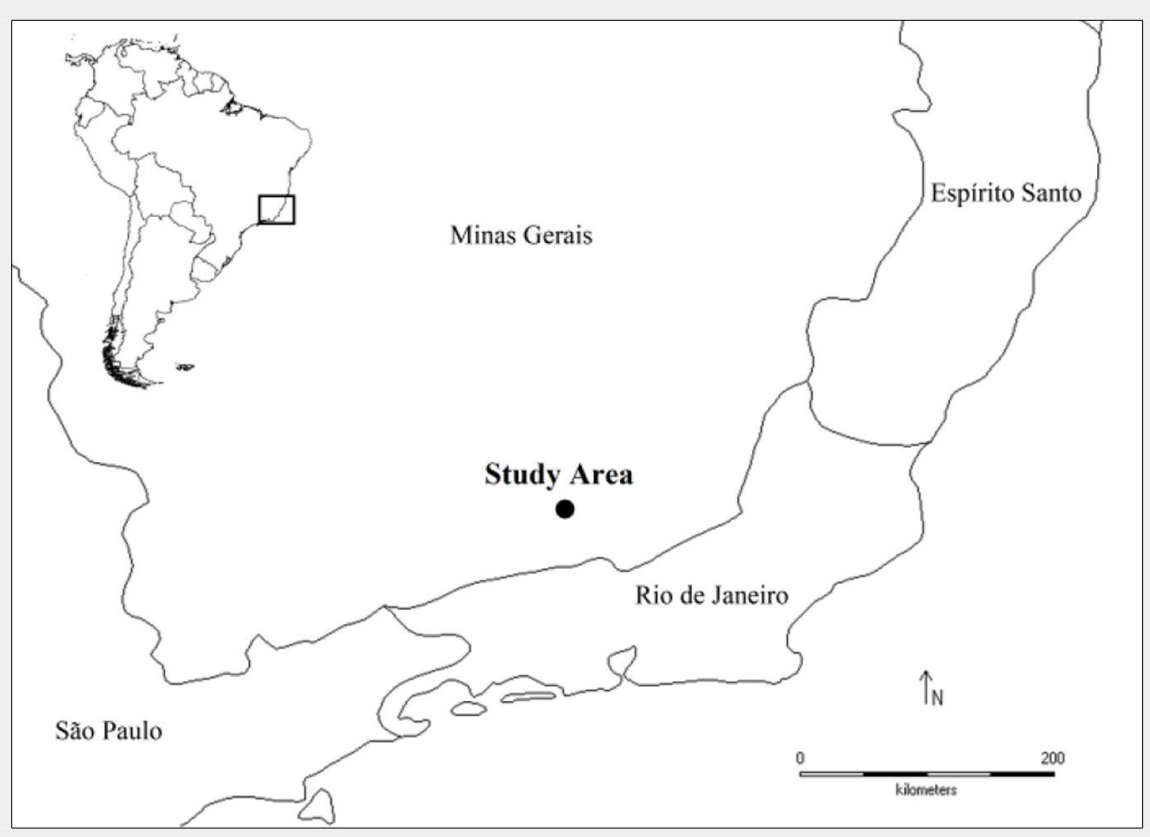

Fig. 1 - Geographical location of the study area, a secondary forest regenerating after the abandonment of a shaded coffee plantation (Coffea arabica) in the Botanical Garden of the Federal University of Juiz de Fora, Juiz de Fora, Minas Gerais, Southeastern Brazil.

the highest rates in January (ca. $300 \mathrm{~mm}$ ), while the annual temperature average is around $18.9{ }^{\circ} \mathrm{C}$ (Fonseca \& Carvalho 2012). The relief is formed by very old rocks, basically gneiss and granite, with predominant soils classified as Dystrophic Yellow Oxisoils (Oliveira-Neto 2014). The forest vegetation is classified as mountainous semideciduous (seasonally) forest according to the Brazilian Vegetation System (IBGE 2012).

The entire area corresponding to the JBUFJF was formerly a coffee crop plantation (Coffea arabica L.) cultivated both in full sun and under the canopy of native forest species, especially Pau-jacaré (Piptadenia gonoacantha [Mart.] J.F.Macbr.), a large size, long-lived pioneer tree species native to Brazilian seasonal forests and exploited for tannins (Carvalho 2003). The current forest cover of JB-UFJF results from the abandonment of coffee crops and cattle pastures, which gave rise to a mosaic of different successional stages related to the past use of the area. Forest patches are found from early stages of succession after grazing abandonment to more mature woodlands with low anthropogenic interference, characterized by the presence of large remnant native trees.

This study was conducted in a forest patch (a section of a former coffee plantation grown under $P$. gonoacantha canopy), abandoned about 70 years ago (OliveiraNeto 2014). The surveyed area covers approximately 15 ha (center coordinates: $21^{\circ} 43^{\prime} 59.216^{\prime \prime}$ S, $91^{\circ} 22^{\prime} 19.359^{\prime \prime} \mathrm{W}$ ), and represents an intermediate succession stage according to criteria established by the Brazilian Environmental Resolution (CONAMA 392/2007).
Twenty-five permanent plots of $20 \times 20 \mathrm{~m}$ $\left(400 \mathrm{~m}^{2}\right)$ were established in the surveyed area, with a total sampled area of 1 ha (Felfili et al. 2005). We measured the diameter of all living and standing dead individual trees with a $\mathrm{DBH} \geq 5 \mathrm{~cm}$ (diameter at breast height at $1.3 \mathrm{~m}$ from the soil). The botanical material collected was identified using the CESJ herbarium collection from UFJF and the collection of Plant Ecology Laboratory (UFJF). The specific nomenclature and the abbreviations of the names of authorities follow the Species List of Brazilian Flora (http://floradobrasil.jbrj.gov.br/). The classification of botanical families followed the APG III system (APG 2009).

The characterization of the tree community was carried out by calculating following phytosociological parameters for each species: species richness $(S)$, absolute density $(A D)$, total and individual basal area $(B A)$, relative frequency $(R F)$, relative density $(R D)$, relative dominance (RDo), and importance value (IV, Kent \& Coker 1992 eqn. 1):

$$
I V=R F+R D+R D o
$$

Species diversity was estimated using the Shannon's diversity index ( $H^{\prime}-$ eqn. 2$)$ :

$$
H^{\prime}=-\sum_{i=1}^{n} p_{i} \log p_{i}
$$

where $p_{\mathrm{i}}$ is the proportion of the $i$-th species, and $n$ is the total number of species. This index is more influenced by species with a lower density, i.e., locally rare (Magurran 2004). The Pielou's evenness index $(J)$ was used to estimate the species uniformity of the community.

\section{Results}

We sampled a total of 1927 individual trees, of which 1837 were living trees. We found 117 species belonging to 84 genera and 33 families (Tab. 1). The five families with the highest species richness were Fabaceae (17 species; $14.6 \%$ of the total), Myrtaceae (10; $11.6 \%)$, Moraceae (9; 7.8\%), Lauraceae $(8 ; 6.9 \%)$, and Annonaceae (7; $6.0 \%)$, which together accounted for $46.2 \%$ of the total number of sampled species. Among the most abundant families in the area, five had the highest density of individuals: Arecaceae (824 individuals; $44.9 \%$ of the total), Fabaceae (234; $12.7 \%)$, Annonaceae $(186 ; 10.1 \%)$, Rubiaceae $(66 ; 3.6 \%)$, and Sapindaceae $(65 ; 3.5 \%)$, which together accounted for $74.8 \%$ of the total number of sampled individuals.

We also sampled 89 standing dead trees, representing $4.6 \%$ of all sampled trees. The community had a total basal area of 43.61 $\mathrm{m}^{2} \mathrm{ha}^{-1}$, and a strong dominance of few species. The five species with the highest importance value (IV) in the community were Euterpe edulis (22.9\%), Piptadenia gonoacantha (16.5\%), Xylopia sericea (5.7\%), Annona cacans (3.5\%), and Syagrus romanzoffiana (3.3\%), which together amounted to $51.9 \%$ of the total IV. Euterpe edulis had the highest abundance (759 ind ha ${ }^{-1}$ ), represented $41.2 \%$ of the total, and was present in all plots. Not surprisingly, the species with the highest basal area was $P$. gonoacantha $\left(16.60 \mathrm{~m}^{2} \mathrm{ha}^{-1}\right)$, representing $38.2 \%$ of the total.

The value of Shannon's diversity species index for the whole community was $H^{\prime}=$ 2.92, while that of the Pielou evenness index was $J=0.61$. Excluding the high-density species $E$. edulis from the analyses, the highest values were $H^{\prime}=3.83$ and $J=0.80$.

With 117 species in a standard 1-ha sampled area, we found the highest species richness compared to secondary patches with the same vegetation type in the region, which registered 105 (Brito \& Carvalho 2014), 78 (Fonseca \& Carvalho 2012) and 48 species (Moreira 2014), respectively. Among the rare species in the sample, we found the climax species Abarema cochliocarpos and some late secondary species (such as Andira fraxinifolia, Ceiba speciosa, Aspidosperma australe, Inga cylindrica and Nectandra lanceolata), suggesting the potential of the area to conserve species with advanced succession. Based on the lists of threatened species prepared by the IUCN (2016), four species were considered "vulnerable" for the state of Minas Gerais: Dalbergia nigra, Euterpe edulis, Ocotea odorifera, and Protium heptaphyllum. The high-density species E. edulis is also in the "endangered" category. These same species were also found on the Brazilian official list of endangered flora species (MMA 2011). These results demonstrate the relevance of the study area in terms of high tree species richness, including endangered species. 
Tab. 1 - Results of the phytosociological survey of the tree population sampled in the secondary forest regenerating after the abandonment of a shaded coffee plantation (Coffea arabica) in the Botanical Garden of the Federal University of Juiz de Fora, Juiz de Fora, Minas Gerais (southeastern Brazil). Species are listed in a decreasing order of importance value (IV). (AD): absolute density $\left(h^{-1}\right)$; $(B A)$ : basal area $\left(\mathrm{m}^{2}\right.$ ha $\left.{ }^{-1}\right)$; $(F A)$ : absolute frequency; $(R D)$ : relative density; (RDo): relative dominance; (RF): relative frequency; (IV): importance value; (\%IV): importance value as percentage; (*): Non-native species.

\begin{tabular}{|c|c|c|c|c|c|c|c|c|c|c|c|c|c|c|c|c|c|}
\hline Species & $A D$ & BA & FA & DR & RDo & RF & IV & IV(\%) & Species & AD & BA & FA & RD & RDo & RF & IV & IV(\%) \\
\hline Euterpe edulis & 759 & 99.518 & 25 & 41.29 & 22.82 & 4.59 & 68.70 & 22.90 & Miconia cinnamomifolia & 1 & 0.2037 & 1 & 0.05 & 0.47 & 0.18 & 0.70 & 0.23 \\
\hline Piptadenia gonoacantha & 130 & 166.077 & 23 & 7.07 & 38.08 & 4.22 & 49.37 & 16.46 & Cordia glabrata & 2 & 0.0917 & 2 & 0.11 & 0.21 & 0.37 & 0.69 & 0.23 \\
\hline Xylopia sericea & 111 & 31.211 & 22 & 6.04 & 7.16 & 4.04 & 17.23 & 5.74 & Myrtaceae sp. (2) & 6 & 0.0612 & 1 & 0.33 & 0.14 & 0.18 & 0.65 & 0.22 \\
\hline Annona cacans & 43 & 25.618 & 13 & 2.34 & 5.87 & 2.39 & 10.60 & 3.53 & Casearia arborea & 3 & 0.0299 & 2 & 0.16 & 0.07 & 0.37 & 0.60 & 0.20 \\
\hline Syagrus romanzoffiana & 63 & 10.768 & 21 & 3.43 & 2.47 & 3.85 & 9.75 & 3.25 & Cedrela fissilis & 2 & 0.0537 & 2 & 0.11 & 0.12 & 0.37 & 0.60 & 0.20 \\
\hline Machaerium nyctitans & 42 & 12.725 & 11 & 2.29 & 2.92 & 2.02 & 7.22 & 2.41 & Ocotea odorifera & 2 & 0.0526 & 2 & 0.11 & 0.12 & 0.37 & 0.60 & 0.20 \\
\hline Eriobotrya japônica* & 45 & 0.3247 & 13 & 2.45 & 0.74 & 2.39 & 5.58 & 1.86 & Ficus adhatodifolia & 2 & 0.0515 & 2 & 0.11 & 0.12 & 0.37 & 0.59 & 0.20 \\
\hline Sparattosperma leucanthum & 21 & 0.8277 & 11 & 1.14 & 1.90 & 2.02 & 5.06 & 1.69 & Brosimum guianense & 3 & 0.0223 & 2 & 0.16 & 0.05 & 0.37 & 0.58 & 0.19 \\
\hline Coutarea hexandra & 31 & 0.3009 & 10 & 1.69 & 0.69 & 1.83 & 4.21 & 1.40 & Ficus enormis & 2 & 0.0309 & 2 & 0.11 & 0.07 & 0.37 & 0.55 & 0.18 \\
\hline Xylopia brasiliensis & 20 & 0.4631 & 11 & 1.09 & 1.06 & 2.02 & 4.17 & 1.39 & Ficus insipida & 2 & 0.0298 & 2 & 0.11 & 0.07 & 0.37 & 0.54 & 0.18 \\
\hline Cabralea canjerana & 20 & 0.1247 & 14 & 1.09 & 0.29 & 2.57 & 3.94 & 1.31 & Annona neolaurifolia & 2 & 0.0186 & 2 & 0.11 & 0.04 & 0.37 & 0.52 & 0.17 \\
\hline Piper arboreum & 28 & 0.0789 & 12 & 1.52 & 0.18 & 2.20 & 3.91 & 1.30 & Casearia sp. (1) & 2 & 0.0119 & 2 & 0.11 & 0.03 & 0.37 & 0.50 & 0.17 \\
\hline Piptocarpha macropoda & 14 & 0.4885 & 11 & 0.76 & 1.12 & 2.02 & 3.90 & 1.30 & Ocotea villosa & 2 & 0.0091 & 2 & 0.11 & 0.02 & 0.37 & 0.50 & 0.17 \\
\hline Dalbergia nigra & 24 & 0.2381 & 11 & 1.31 & 0.55 & 2.02 & 3.87 & 1.29 & Geonoma schottiana & 2 & 0.0080 & 2 & 0.11 & 0.02 & 0.37 & 0.49 & 0.16 \\
\hline Alchornea glandulosa & 17 & 0.2960 & 12 & 0.92 & 0.68 & 2.20 & 3.81 & 1.27 & Campomanesia laurifolia & 2 & 0.0070 & 2 & 0.11 & 0.02 & 0.37 & 0.49 & 0.16 \\
\hline Nectandra oppositifolia & 17 & 0.2358 & 12 & 0.92 & 0.54 & 2.20 & 3.67 & 1.22 & Stryphnodendron adstringens & 2 & 0.0064 & 2 & 0.11 & 0.01 & 0.37 & 0.49 & 0.16 \\
\hline Maprounea guianensis & 17 & 0.1538 & 12 & 0.92 & 0.35 & 2.20 & 3.48 & 1.16 & Sloanea hirsuta & 2 & 0.0062 & 2 & 0.11 & 0.01 & 0.37 & 0.49 & 0.16 \\
\hline Cupania ludowigii & 17 & 0.1161 & 12 & 0.92 & 0.27 & 2.20 & 3.39 & 1.13 & Citrus sp. (1) & 2 & 0.0048 & 2 & 0.11 & 0.01 & 0.37 & 0.49 & 0.16 \\
\hline Syzygium jambos* & 16 & 0.2592 & 10 & 0.87 & 0.59 & 1.83 & 3.30 & 1.10 & Luehea grandiflora & 1 & 0.0935 & 1 & 0.05 & 0.21 & 0.18 & 0.45 & 0.15 \\
\hline Sorocea guilleminiana & 19 & 0.1059 & 11 & 1.03 & 0.24 & 2.02 & 3.29 & 1.10 & Solanum leucodendron & 2 & 0.0683 & 1 & 0.11 & 0.16 & 0.18 & 0.45 & 0.15 \\
\hline Allophylus sericeus & 14 & 0.2740 & 8 & 0.76 & 0.63 & 1.47 & 2.86 & 0.95 & Schefflera morototoni & 1 & 0.0911 & 1 & 0.05 & 0.21 & 0.18 & 0.45 & 0.15 \\
\hline Guapira hirsuta & 15 & 0.0675 & 9 & 0.82 & 0.15 & 1.65 & 2.62 & 0.87 & Solanum pseudoquina & 2 & 0.0522 & 1 & 0.11 & 12 & 0.18 & 0.41 & 0.14 \\
\hline Siparuna guianensis & 12 & 0.0319 & 9 & 0.65 & 0.07 & 1.65 & 2.38 & 0.79 & Tibouchina granulosa & 1 & 0.0741 & 1 & 0.05 & 0.17 & 0.18 & 0.41 & 0.14 \\
\hline Ocotea puberula & 9 & 0.1759 & 8 & 0.49 & 0.40 & 1.47 & 2.36 & 0.79 & Guatteria guianensis & 3 & 0.0223 & 1 & 0.16 & 0.05 & 0.18 & 0.40 & 0.13 \\
\hline Cupania oblongifolia & 14 & 0.1245 & 7 & 0.76 & 0.29 & 1.28 & 2.33 & 0.78 & Abarema cochliacarpos & 2 & 0.0270 & 1 & 0.11 & 0.06 & 0.18 & 0.35 & 0.12 \\
\hline Ceiba speciosa & 10 & 0.0725 & 7 & 0.54 & 0.17 & 1.28 & 1.99 & 0.66 & Cassia ferruginea & 2 & 0.0238 & 1 & 0.11 & 0.05 & 0.18 & 0.35 & 0.12 \\
\hline Trichilia elegans & 8 & 0.0373 & 8 & 0.44 & 0.09 & 1.47 & 1.99 & 0.66 & Morus nigra & 1 & 0.0454 & 1 & 0.05 & 0 & 0.18 & 0.34 & 0.11 \\
\hline Cordia ecalyculata & 11 & 0.0620 & 6 & 0.60 & 0.14 & 1.10 & 1.84 & 0.61 & Ocotea aciphylla & 2 & 0.0207 & 1 & 0.11 & 0.05 & 0.18 & 0.34 & 0.11 \\
\hline Lacistema pubescens & 7 & 0.0242 & 7 & 0.38 & 0.06 & 1.28 & 1.72 & 0.57 & Eugenia cerasiflora & 2 & 0.0112 & 1 & 0.11 & 0.03 & 0.18 & 0.32 & 0.11 \\
\hline Matayba elaeagnoides & 8 & 0.0519 & 6 & 0.44 & 0.12 & 1.10 & 1.66 & 0.55 & Casearia sylvestris & 1 & 0.0326 & 1 & 0.05 & 0.07 & 0.18 & 0.31 & 0.10 \\
\hline Machaerium stiptatum & 8 & 0.0462 & 6 & 0.44 & 0.11 & 1.10 & 1.64 & 0.55 & Guatteria guianensis & 2 & 0.0067 & 1 & 0.11 & 0.02 & 0.18 & 0.31 & 0.10 \\
\hline Tabernaemontana laeta & 10 & 0.2324 & 3 & 0.54 & 0.53 & 0.55 & 1.63 & 0.54 & Inga cylindrica & 1 & 0.0293 & 1 & 0.05 & 0.07 & 0.18 & 0.31 & 0.10 \\
\hline Cecropia glaziovii & 6 & 0.1848 & 4 & 0.33 & 0.42 & 0.73 & 1.48 & 0.49 & Hortia brasiliana & 1 & 0.0284 & 1 & 0.05 & 0.07 & 0.18 & 0.30 & 0.10 \\
\hline Albizia polycephala & 7 & 0.1394 & 4 & 0.38 & 0.32 & 0.73 & 1.43 & 0.48 & Pseudobombax grandiflo & 1 & 0.0131 & 1 & 0.05 & 0.03 & 0.18 & 0.27 & 0.09 \\
\hline Allophylus edulis & 6 & 0.0706 & 5 & 0.33 & 0.16 & 0.92 & 1.41 & 0.47 & Guettarda viburnoides & 1 & 0.0124 & 1 & 0.05 & 0.03 & 0.18 & 0.27 & 0.09 \\
\hline Aparisthmium cordatum & 5 & 0.1551 & 4 & 0.27 & 0.36 & 0.73 & 1.36 & 0.45 & Nectandra lanceolata & 1 & 0.0095 & 1 & 0.05 & 0.02 & 0.18 & 0.26 & 0.09 \\
\hline Cupania vernalis & 6 & 0.1159 & 4 & 0.33 & 0.27 & 0.73 & 1.33 & 0.44 & Siphoneugenea sp. (1) & 1 & 0.0084 & 1 & 0.05 & 0.02 & 0.18 & 0.26 & 0.09 \\
\hline Annona sylvatica & 5 & 0.0354 & 5 & 0.27 & 0.08 & 0.92 & 1.27 & 0.42 & Myrtaceae sp. (1) & 1 & 0.0069 & 1 & 0.05 & 0.02 & 0.18 & 0.25 & 0.08 \\
\hline Ocotea corymbosa & 7 & 0.0303 & 4 & 0.38 & 0.07 & 0.73 & 1.18 & 0.39 & Myrsine coriácea & 1 & 0.0067 & 1 & 0.05 & 0.02 & 0.18 & 0.25 & 0.08 \\
\hline Guapira opposita & 5 & 0.0717 & 4 & 0.27 & 0.16 & 0.73 & 1.17 & 0.39 & Zanthoxylum fagara & 1 & 0.0054 & 1 & 0.05 & 0.01 & 0.18 & 0.25 & 0.08 \\
\hline Ficus clusiifolia & 5 & 0.0597 & 4 & 0.27 & 0.14 & 0.73 & 1.14 & 0.38 & Cheiloclinium serratum & 1 & 0.0048 & 1 & 0.05 & 0.01 & 0.18 & 0.25 & 0.08 \\
\hline Apuleia leiocarpa & 5 & 0.0559 & 4 & 0.27 & 0.13 & 0.73 & 1.13 & 0.38 & Dalbergia frutescens & 1 & 0.0048 & 1 & 0.05 & 0.01 & 0.18 & 0.25 & 0.08 \\
\hline Seguieria langsdorffii & 6 & 0.1707 & 2 & 0.33 & 0.39 & 0.37 & 1.08 & 0.36 & Lamanonia grandistipularis & 1 & 0.0044 & 1 & 0.05 & 0.01 & 0.18 & 0.25 & 0.08 \\
\hline Eugenia florida & 5 & 0.0191 & 4 & 0.27 & 0.04 & 0.73 & 1.05 & 0.35 & Trichilia hirta & 1 & 0.0044 & 1 & 0.05 & 0.01 & 0.18 & 0.25 & 0.08 \\
\hline Vitex sellowiana & 4 & 0.0138 & 4 & 0.22 & 0.03 & 0.73 & 0.98 & 0.33 & Peltophorum dubium & 1 & 0.0040 & 1 & 0.05 & 0.01 & 0.18 & 0.25 & 0.08 \\
\hline Myrcia splendens & 4 & 0.0526 & 3 & 0.22 & 0.12 & 0.55 & 0.89 & 0.30 & Cybistax antisyphilitica & 1 & 0.0039 & 1 & 0.05 & 0.01 & 0.18 & 0.25 & 0.08 \\
\hline Croton floribundus & 3 & 0.0646 & 3 & 0.16 & 0.15 & 0.55 & 0.86 & 0.29 & Platypodium elegans & 1 & 0.0039 & 1 & 0.05 & 0.01 & 0.18 & 0.25 & 0.08 \\
\hline Vernonanthura divaricata & 3 & 0.1378 & 2 & 0.16 & 0.32 & 0.37 & 0.85 & 0.28 & Trichilia catigua & 1 & 0.0030 & 1 & 0.05 & 0.01 & 0.18 & 0.24 & 0.08 \\
\hline Aspidosperma australe & 4 & 0.0326 & 3 & 0.22 & 0.07 & 0.55 & 0.84 & 0.28 & Andira fraxinifolia & 1 & 0.0029 & 1 & 0.05 & 0.01 & 0.18 & 0.24 & 0.08 \\
\hline Guarea macrophylla & 1 & 0.2507 & 1 & 0.05 & 0.57 & 0.18 & 0.81 & 0.27 & Aspidosperma spruceanum & 1 & 0.0029 & 1 & 0.05 & 0.01 & 0.18 & 0.24 & 0.08 \\
\hline Luehea divaricata & 4 & 0.0853 & 2 & 0.22 & 0.20 & 0.37 & 0.78 & 0.26 & Prunus myrtifolia & 1 & 0.0029 & 1 & 0.05 & 0.01 & 0.18 & 0.24 & 0.08 \\
\hline Jacaranda macranta & 3 & 0.0239 & 3 & 0.16 & 0.05 & 0.55 & 0.77 & 0.26 & Casearia oblongifolia & 1 & 0.0024 & 1 & 0.05 & 0.01 & 0.18 & 0.24 & 0.08 \\
\hline Maclura tinctoria & 3 & 0.0197 & 3 & 0.16 & 0.05 & 0.55 & 0.76 & 0.25 & Dalbergia villosa & 1 & 0.0024 & 1 & 0.05 & 0.01 & 0.18 & 0.24 & 0.08 \\
\hline
\end{tabular}

\section{Discussion}

The richest families in this study, Lauraceae, Myrtaceae, and Moraceae, follow the phytogeographical pattern found by Oliveira-Filho \& Fontes (2000) for semideciduous seasonal forest formations in southeastern Brazil. The composition in botanical families suggest a more advanced successional stage for the surveyed area, due in particular to the dominance of fami- lies with zoochorous dispersal of fleshy fruits and large seeds, such as Annonaceae, Lauraceae, Myrtaceae, and Moraceae (Tabarelli \& Peres 2002). Myrtaceae species are considered important for the development of low-growing vegetation communities, especially because their fruits are appreciated and dispersed by animals (Tabarelli et al. 1994). The Ficus genus stands out with four species within the
Moraceae family, and according to Carauta (1989), fig trees are key components of many tropical forests, since a wide variety of animals feeds on their fruits, including mammals, birds, and even fish. These species are responsible for the dispersion of seeds, thus helping the regeneration of the forest. The Lauraceae family, which had one of the largest importance value in the study area, is considered to be relevant in 
the structural composition of large areas of the Atlantic Forest (Tabarelli et al. 1999, Tabarelli \& Peres 2002).

The high species richness in terms of families including species with zoochoric dis semination can be directly related to two reasons: (1) the former anthropogenic management of the surveyed area, especially due to the former presence of coffee crops under shading; and (2) the high density of $E$. edulis trees in the community. Several studies showed that tropical forests grown after coffee crop abandonment have a high diversity of animal species and native plants (Perfecto et al. 1996, Pascarella et al. 2000, López-Gómez et al. 2008). It is believed that the trees of the former shading canopy remained after the abandonment could play an important role in the following succession, as they supply seeds for regeneration stored in the shaded soil, and shelter the recruitment of trees under their canopies even after the canopy closure (Chazdon 2008). From this perspective, the predominant species $E$. edulis in the investigated area could have substantially contributed to the observed diversity by attracting animals that scatter seeds of other tree species, thus effectively contributing to the creation of the forest food web (Reis \& Kageyama 2000).

The Shannon's diversity index $\left(H^{\prime}=2.92\right)$ observed in this study was consistent with those found in similar studies on nearby secondary forests with the same vegetation type. For example, Fonseca \& Carvalho (2012) obtained an index $H^{\prime}=2.82$ in a forest fragment at the regeneration stage, while Moreira (2014) observed a value of 2.84 in a small forest after more than 40 years since the abandonment, and Brito \& Carvalho (2014) reported a value of 3.30 in a forest patch in an intermediate stage of succession. However, the forest patch analyzed in this study showed a lower diversity value as compared with the other three adjoining areas. Indeed, the lower evenness value $(J=0.61)$ reflects the high density of $E$. edulis trees, indicating that only $61 \%$ of the maximum hypothetical diversity $\left(H^{\prime}\right)$ was reached in the studied area. On the other hand, excluding this species from computations resulted in diversity indices of $H^{\prime}=3.82$ and $J=0.81$ (more than $80 \%$ of the maximal hypothetical diversity). Slightly larger values were found by Garcia (2007) and Valente et al. (2011) in nearby conserved forests $\left(H^{\prime}=4.29\right.$ and $H^{\prime}=4.11$, respectively) located in remote areas not inserted into the urban context. Such comparisons better highlight the results obtained in the study area, where the dominance of a single species ( $E$. edulis) did not hamper the presence in the community of other 116 species, resulting in the highest richness and one of the highest diversities $\left(H^{\prime}\right)$ observed for forests in the region.

In this study, phytosociological analysis revealed a strong ecological dominance by $E$. edulis and $P$. gonoacantha. According to Kent \& Coker (1992), the most important species in terms of importance value (IV) are those better exploiting the habitat resources, representing the core of the community structure. According to Reis et al. (2000), E. edulis stands occur in habitat rich in water, organic matter, and shade. Indeed, the presence of springs and drainage channels in the study area suggests a high moisture content, which apparently is the key to the success of this species. Forest use history also contributed to the high density of E. edulis. This species occurs naturally in the area, but its density increased after the management related to the former coffee plantation. When intercropped with $P$. gonocantha, a rapid-growth large species used for coffee shading, it is likely that $E$. edulis found its optimal conditions, as it requires shading in the early stages of development. In fact, a high incidence of sunlight can result in drying of recalcitrant seeds of this species in the soil seed bank (Queiroz 2000, Reis et al. 1999).

The low percentage of dead standing trees observed in this study (4.7\%) suggests that the forest community is in a more advanced successional stage as compared with studies on the same vegetation type in the area, whose percentage exceed 15\% (Fonseca \& Carvalho 2012, Brito \& Carvalho 2014, Moreira 2014). According to Chazdon (2008), more developed forests tend to have a lower percentage of dead trees. This is fairly common in secondary forests where pioneer species are replaced by secondary species along the succession. With a low dominance of pioneer species, competition among lower diameter classes decreases, and thus the mortality rate in competition tends to be lower (Chazdon 2008).

Overall, our results support the hypothesis of a well-structured community in more advanced successional stages in relation to nearby secondary forests with similar periods of abandonment. The dominant species $E$. edulis seems to be an efficient attractor of associated fauna and flora. Our findings suggests that coffee cultivation under shading, intercropped with native species of commercial interest, can be a good option for both production and conservation of species diversity.

We also found a peculiar combination of species recorded for the first time for semideciduous seasonal forest formations of the Juiz de Fora region, mainly attributed to the high density of $E$. edulis and the high basal area of Piptadenia gonoacantha. This species combination, along with the naturalization of exotic species (Coffea arabica, Eryobotria japonica, Morus nigra, etc.) and the proximity to a major urban center, suggests that this area can be considered a "novel ecosystem" sensu Hobbs et al. (2006). According to these authors, "novel ecosystems" arise from altered biotic elements, such as soil fertility, degradation, and the introduction of species. Many characteristics of our study area are similar to those observed for "novel ecosystems" in abandoned coffee plantations in Puerto
Rico (Lugo \& Helmer 2004), e.g., the increase in density of large individuals (DBH $>55 \mathrm{~cm}$ ) of $P$. gonocantha in comparison with the surrounding forest communities, or the presence of dominant species in the community (Mascaro et al. 2012). In this study, only two native species (E.edulis and P. gonacantha) accounted for $48.4 \%$ of individuals.

\section{Conclusion}

Areas with a history of intensive coffee farming, especially monocultures, are common throughout southeast Brazil. Many of these areas were abandoned and regenerated naturally thereafter. Understanding these "novel ecosystems" is fundamental for conservation of biodiversity. In this study, we found 117 species belonging to 84 genera and 33 families in a forest patch grown in a former coffee plantation 70 years since its abandonment, This suggesting the potential of such secondary ecosystems in the conservation of local species. Our results showed that coffee cultivation under shading, intercropped with native species of commercial interest, could be a good option for both production and biodiversity conservation.

According to Marris et al. (2013), the adoption of the "novel ecosystems" concept in the analysis of ecological conditions of forests may improve the study of new features acquired in response to anthropogenic impacts and promote the conservation of ecosystems previously considered of poor interest.

\section{Acknowledgements}

We thank the researchers from Herbarium CESJ-UFJF, especially Daniel S. Pifano, Kelly Antunes and Ricardo Castro for their assistance in botanical identification; students of Plant Ecology Laboratory (Department of Botany, UFJF) and José Carlos, for assistance in the field work; Dr. Guilherme R. Rabelo (UENF) and Dr. Arthur S. M. Valente (IEF), for revising the manuscript; Postgraduate Program in Ecology (PGECOL-UFJF) for logistical support; CAPES, for granting scholarships to N.E. OliveiraNeto; and FAPEMIG, for financial support (Project APQ 04438/10).

\section{References}

APG (2009). An update of the Angiosperm phylogeny group classification for the orders and families of flowering plants: APG III. Botanical Journal of Linnean Society 161: 105-121. - doi: 10.1111/j.1095-8339.2009.00996.x

Ayres JM, Fonseca GAB, Rylands AB, Queiros $H L$, Pinto LP, Masterson Cavalcanti D RB (2005). Os corredores ecológicos das florestas tropicais do Brasil [Ecological corridors of tropical forests in Brazil]. Sociedade Civil Mamirauá, Belém, Brazil, pp. 255. [in Portuguese] Brito PS, Carvalho FA (2014). Estrutura e diversidade arbórea da Floresta Estacional Semidecidual secundária no Jardim Botânico da Universidade Federal de Juiz de Fora [Structure and tree diversity of secondary semideciduous for- 
est in the Botanical Garden of the Federal University of Juiz de Fora] Rodriguésia 64: 817-830. [in Portuguese]

Carauta JPP (1989). Ficus (Moraceae) no Brasil: Conservação e Taxonomia [Ficus (Moraceae) in Brazil: conservation and taxonomy] Albertoa 2: 1-365. [in Portuguese]

Carvalho FA, Abreu RC, Barros KART, Fonseca SN, Santiago DS, Oliveira DE, Assis DC, Pimentel FO, Lyra MFB, Furtado SG (2014). A comunidade arbórea regenerante de um "ecossistema emergente" dominado pela espécie exótica invasora Pinus elliottii Engelm [Regenerating tree community of an "emerging ecosystem" dominated by invasive alien species Pinus elliottii Engelm]. Interciencia 39:307-312. [in Portuguese] [online] URL: http://search.proquest. com/openview/32ebc5bodf2f16b570833486eof deoo $4 / 1$

Carvalho PER (2003). Espécies arbóreas brasileiras [Brazilian tree species]. Colombo, Embrapa Florestas, Brasília, Brazil, pp. 1039. [in Portuguese]

Chazdon RL (2008). Chance and determinism in tropical forest sucession. In: "Tropical Forest Community Ecology" (Carson WP, Schnitzer SA eds). Blackwell Publishing, Chichester, UK, pp. 384-408.

Chazdon RL, Peres CA, Dent D, Sheil D, Lugo AE, Lamb D, Stork NE, Miller SE (2009). The potential for species conservation in tropical secondary forests. Conservation Biology 23 (6): 1406-1417. - doi: 10.1111/j.1523-1739.2009.01338.x Felfili JM, Carvalho FA, Haidar RF (2005). Manual para o monitoramento de parcelas permanentes nos biomas Cerrado e Pantanal [Manual for monitoring of permanent plots in the Cerrado e Pantanal biomes]. Universidade de Brasília. Editora da UNB, Brasília, Brazil, pp. 55. [in Portuguese]

Fonseca CR, Carvalho FA (2012). Aspectos florísticos e fitossociológicos da comunidade arbórea de um fragmento urbano de Floresta Atl'ntica (Juiz de Fora, MG, Brasil) [Floristic and phytosociological aspects of the tree community of an urban fragment of Atlantic Forest (Juiz de Fora, MG, Brazil)]. Bioscience Journal 28: 820-832. [in Portuguese]

Fonseca GAB (1985). The vanishing Brazilian Atlantic Forest. Biological Conservation 34: 1734. - doi: 10.1016/0006-3207(85)90055-2

Garcia PO (2007). Estrutura e composição do estrato arbóreo em diferentes trechos da reserva biológica municipal Santa Cândida, Juiz de Fora-MG [Structure and composition of tree communities in different parts of the municipal biological reserve Santa Candida, Juiz de foraMG]. Master's Dissertation, Federal University of Juiz de Fora, Juiz de Fora, MG, Brazil, pp. 104. [in Portuguese]

Guariguata MR, Ostertag R (2001). Neotropical secondary succession: changes in structural and functional characteristics. Forest Ecology and Management 148: 185-206. - doi: 10.1016/So 378-1127(00)00535-1

Hobbs RJ, Arico S, Aronson J, Baron JS, Bridgewater P, Cramer VA, Epstein PR, Ewel JJ, Klink CA, Lugo AE, Norton D, Ojima D, Richardson $D M$, Sanderson EW, Valladares $F$, Vila $M$, Zamora R, Zobel M (2006). Novel ecosystems: theoretical and management aspects of the new ecological world order. Global Ecology and Biogeography 15 (1): 1-7. - doi: 10.1111/j.1466-82 2X.2006.00212.X

IBGE (2012). Manual técnico da vegetação brasileira [Technical manual of Brazilian vegetation]. Fundação Instituto Brasileiro de Geografia e Estatística, Rio de Janeiro, Brazil, pp. 323. [in Portuguese]

IUCN (2016). The IUCN red list of threatened species (version 2016.1). Web site. [online] URL: http://www.iucnredlist.org

Kent M, Coker P (1992). Vegetation description and analysis. John Wiley and Sons, New York. USA, pp. 363.

López-Gómez AM, Williams-Linera G, Manson RH (2008). Tree species diversity and vegetation structure in shade coffee farms in Veracruz, Mexico. Agriculture, Ecosystems and Environment 124: 160-172. - doi: 10.1016/j.agee.2007.09. 008

Lugo AE, Helmer E (2004). Emerging forests on abandoned land: Puerto Rico's new forests. Forest Ecology and Management 190: 145-161. doi: 10.1016/j.foreco.2003.09.012

Magurran AE (2004). Measuring biological diversity. Blackwell Science, Oxford, UK, pp. 215.

Mascaro J, Hughes RF, Schnitzer SA (2012). Novel forests maintain ecosystem processes after the decline of native tree species. Ecological Monographs 82: 221-228. - doi: 10.1890/11-1014.1 MMA (2011). Instrução Normativa $n^{\circ} 6$ de 23 de setembro de 2008 [Normative instruction $n^{\circ} 6$ of September 23, 2008]. Ministério do medio Ambiente, Brasília, Brazil, web site. [in Portuguese] [online] URL: http://www.mma.gov. br/estruturas/179/_arquivos/179_051220080336 15.pdf

Marris E, Mascaro J, Ellis EC (2013). Perspective: is everything a novel ecosystem? If so, do we need the concept? In: "Novel Ecosystems: Intervening in the New Ecological World Order" (Hobbs RJ, Higgs ES, Hall CM eds). John Wiley \& Sons, Chichester, UK, pp. 345-349. doi: 10.1002/9781118354186.ch41

Moreira B, Carvalho FA (2013). A comunidade arbórea de um fragmento urbano de Floresta Atlântica após 40 anos de sucessão secundária (Juiz de Fora, MG) [Tree community of urban fragment of Atlantic Forest after 40 years of secondary succession (Juiz de fora, MG)]. Biotemas 26: 59-70. - doi: 10.5007/2175-7925.2013 v26n2p59

Moreira B (2014). Estrutura, diversidade e regeneração arbórea de uma Floresta Atlântica secundária submetida à supressão do sub-bosque [Structure, diversity and tree regeneration of a secondary Atlantic Forest subjected to suppression of the understory]. Master's Dissertation in Ecology, Federal University of Juiz de Fora, Juiz de Fora, MG, Brazil, pp. 62. [in Portuguese]

Oliveira-Filho AT, Fontes MAL (2000). Patterns of floristic differentiation among Atlantic Forests in Southeastern Brazil and the influence of climate. Biotropica 32: 793-810. - doi: 10.1111/j.17447429.2000.tboo619.x

Oliveira-Neto NE (2014). Aspectos ecológicos da comunidade arbórea em um trecho de Floresta Atlântica com predominância de Palmito-Juça- ra [Ecological aspects of tree community on a stretch of Atlantic Forest with a predominance of Palmito-Juçara (Euterpe edulis Martius]. Master's Dissertation, Federal University of Juiz de Fora, Juiz de Fora, Brazil, pp. 77.

Pascarella JB, Aide TM, Serrano MI, Zimmerman JK (2000). Land-use history and forest regeneration in the Cayey Mountains, Puerto Rico. Ecosystems 3: 217-228. - doi: 10.1007/\$1002100 00021

Perfecto I, Rice R, Greenberg R, Van Der Voort ME (1996). Shade coffee: a disappearing refuge for biodiversity. Bioscience 46: 598-608. - doi: $10.2307 / 1312989$

Queiroz MH (2000). Biologia do fruto, da semente e da germinação do palmiteiro (Euterpe edulis Martius) [Biology of fruit, seed and germination of the palmito (Euterpe edulis Martius)]. Sellowia 49: 39-49. [in Portuguese]

Reis A, Paulilo MTS, Nakazon EK, Venturi S (1999). Efeito de diferentes níveis de dessecamento na germinação de sementes de Euterpe edulis [Effect of different levels of desiccation on the germination of Euterpe edulis Martius seeds]. Insula 28: 31-42. [in Portuguese]

Reis MS, Fantini AC, Nodari RO, Guerra MP, Reis A (2000). Sustainable yield management of Euterpe edulis Martius (Palmae): a tropical palm tree from the Atlantic tropical Forest -Brazil. Journal of Sustainable Forestry 11: 1-17. - doi: 10.1300/Jo91v11no3_01

Reis A, Kageyama PY (2000). Dispersão de sementes de Euterpe edulis Martius (Palmae) [Seed dispersal of Euterpe edulis Martius (Palmae]. In: "Euterpe edulis Martius (Palmiteiro): Biologia, conservação e Manejo" (Reis A, Kageyama PY eds). Herbário Barbosa Rodrigues, Itajaí, pp. 60-80. [in Portuguese]

Ribeiro MC, Metzger JP, Martensen AC, Ponzoni FJ, Hirota MM (2009). The Brazilian Atlantic Forest: how much is left, and how is the remaining forest distributed? Implications for conservation. Biological Conservation 142: 11411153. - doi: 10.1016/j.biocon.2009.02.021

Tabarelli M, Villani JP, Mantovani W (1994). Estudo comparativo da vegetação de dois trechos de floresta secundária no Núcleo Santa Virginia, Parque Estadual da Serra do Mar, SP. [Comparative study of the vegetation of two sections of secondary forest in Santa Viriginia, State Park of Serra do Mar, SP]. Revista Instituto Florestal 6: 1-11. [in Portuguese]

Tabarelli M, Mantovani W, Peres CA (1999). Effects of habitat fragmentation on plant guild structure in the montane Atlantic forest of southeastern Brazil. Biological Conservation 91: 119-127. - doi: 10.1016/Sooo6-3207(99)00085-3 Tabarelli M, Peres CA (2002). Abiotic and vertebrate seed dispersal in the Brazilian Atlantic forest: implications for forest regeneration. Biological Conservation 106: 165-176. - doi: 10.1016/S0006-3207(01)00243-9

Valente ASM, Garcia PO, Salimena FRG, OliveiraFilho AT (2011). Composição, estrutura e similaridade florística da Floresta Atlântica, na Serra Negra, Rio Preto-MG [Composition, structure and floristic similarity of the Atlantic Forest in Serra Negra, Rio Preto-MG]. Rodriguésia 62: 321-340. [in Portuguese] - doi: 10.1590/2175-786 0201162209 